Ks. Marek STAROWIEYSKI

(Warszawa, UW)

\title{
ELEMENTY AUTOBIOGRAFICZNE W TRZECH MĘCZEŃSTWACH AFRYKAŃSKICH Z III WIEKU
}

Pośród licznych tekstów dotyczących męczenników afrykańskich są trzy Męczeństwa Perpetui i Felicyty, Montanusa, Lucjusza i towarzyszy oraz Mariana i Jakuba, w których znajdują się obszerne fragmenty autobiograficzne. O tych właśnie fragmentach będzie mowa w niniejszym artykule. Stanowią one bowiem pewnego rodzaju unikat w hagiograficznej literaturze wczesnochrześcijańskiej, ponieważ z takimi elementami autobiograficznymi nie spotykamy się $w$ innych pismach martyrologicznych. Temat ten jest ponadto dotąd prawie niezbadany i nawet wielka historia autobiografii $\mathrm{G}$. Mischa wspomina, i to krótko, tylko o Męczeństwie Perpetui i Felicyty ${ }^{1}$. Problem ten, kiedyś już przeze mnie podejmowany, omawiam teraz w formie na nowo przepracowanej²

Te elementy autobiograficzne są dwojakiego rodzaju. Pierwsze z nich to te, które są związane z pobytem męczenników w więzieniu: opowiadają o samym pobycie, o przesłuchaniach, o skazaniu, przynosząc więc dużo wiadomości pożytecznych dla historii męczeństwa. Drugą grupę stanowią opisy wizji, których doznają męczennicy, stanowiąc bardzo cenny materiał dla poznania duchowości męczenników. Przyjmujemy autentyczność tych tekstów w całości, a więc także fragmentów autobiograficznych, ponieważ, jak się wydaje, nie mamy podstaw do ich kontestowania, co powiedziawszy, nie wykluczamy możliwości, że ulegały one z czasem pewnego rodzaju przepracowaniom.

Twierdzi się niekiedy, że Męczeństwo Montanusa, Lucjusza i towarzyszy oraz Męczeństwo Mariana i Jakuba zależą od Męczeństwa Perpetui i Felicyty. Jest to jednak tylko częściowa prawda. Zależność języka tych dwóch Pasji jest pewna i jest związana $\mathrm{z}$ faktem, że ta ostatnia była powszechnie znana i czytana w Afryce, i nie jest rzeczą dziwną, że i nasi autorzy ją znali; ponadto ich autorzy przebywali w Afryce i korzystali z języka powszechnie tam uży-

${ }^{1}$ Por. G. Misch, Geschichte der Autobiographie, Bd. 1/2, Frankfurt a. M. 1950², 519: autor wspomina tylko o Passio SS. Perpetuae et Felicitatis zaznaczając, że napisała ona swój dziennik po punicku (sic!).

${ }^{2}$ Artykuł ten rozwija myśli opublikowanego przed kilku laty mojego referatu: Autobiografie męczenników afrykańskich w III wieku, w: Sympozja Kazimierskie poświęcone kulturze późnego antyku i wczesnego chrześcijaństwa, t. 4, red. B. Iwaszkiewicz-Wronikowska - D. Próchniak, Lublin 2004, 111-126. 
wanego. Z tego też powodu utwory te pozostają także w związku z Aktami św. Cypriana $^{3}$, choć te dwie omawiane przez nas pasje powstały zaledwie dwa lata po śmierci biskupa Kartaginy (†258). Nie możemy także zapomnieć, że te dwie Pasje dzieli od śmierci św. Perpetui i Felicyty zaledwie pięćdziesiąt lat i mają one miejsce na stosunkowo niewielkim terytorium, zbliżonym do siebie kulturowo. Byłoby więc rzeczą dziwną, gdyby te trzy utwory nie miały elementów wspólnych, jak choćby to, że wrzucano męczenników do podobnych więzień z podobnymi ciemnościami, zarówno w Kartaginie jak i w Lambesie ${ }^{4}$.

Jeśli jednak jest wiele podobieństw, to jest także wiele różnic, o czym będzie mowa dalej. Inne są osoby, inny styl, inne sytuacje, inny sposób komponowania tekstu, inne wizje. Męczeństwo Pepetui i Felicyty napisał sprawny pisarz, dwie interesujące nas Pasje autorzy co najwyżej mierni, natomiast o dużych ambicjach literackich; podobnie zresztą, jak fragmenty autobiograficzne pokazują na różne osobowości ich autorów i w inny sposób są one wprowadzane do tekstu.

We wszystkich tych trzech tekstach jest mowa o szczególnej działalności Ducha Świętego i o wizjach; widzimy w nich ponadto pewien rygoryzm i entuzjazm względem męczeństwa ${ }^{5}$. $Z$ tych faktów wyciągano wnioski, że mamy tu do czynienia z tekstami związanymi z montanizmem, który odgrywał ważną rolę w Afryce w tej age of anxiety. Czy to wszystko jednak wystarczy, by móc mówić o nich, jako o tekstach montanistycznych? Po pierwsze, zbyt źle znamy montanizm i mamy zbyt mało źródeł, by go stwierdzić w tych tekstach; po drugie, mowa o działalności Ducha Świętego nie wykracza poza granice ortodoksji; i w końcu po trzecie, jest faktem dobrze znanym, że oczekiwanie na śmierć w więzieniach (i to nie tylko starożytnych) powoduje pewnego rodzaju gorączkę psychologiczna, która z kolei może wywoływać wizje.

Będziemy więc traktowali te trzy teksty jako trzy dzieła niezależne - choć powiązane z sobą, oryginalne, pochodzące ze środowisk ortodoksyjnych choć nie wykluczone, że noszące wpływy montanizmu, które przynoszą nam barwny obraz życia chrześcijan-męczenników afrykańskich z III wieku.

1. Męczeństwo Perpetui i Felicyty (za czasów cesarza Septymiusza Sewera, Kartagina, 7 III 203) $)^{6}$. Wedle słów H. Delehaye, jest to arcydzieło lite-

${ }^{3}$ Por. Acta proconsularia S. Cypriani, PL 3, 1497-1506 lub CSEL 3/3, CX-CXIV lub ed. H. Musurillo, The Acts of the Christian martyrs. Texts and English translations, Oxford 1972, 168-175, tłum. pol. J. Czuj, POK 19, 77-80, lub tłum. M. Michalski, ALP I 142-144, przedruk OŻ IX 394-399.

${ }^{4}$ Por. Passio SS. Perpetuae et Felicitatis 3; Passio SS. Montani et Lucii 3.

${ }^{5}$ Por. np. Passio SS. Perpetuae et Felicitatis 1 i 16; Passio SS. Montani et Lucii 3; Passio Mariani et Jacobi 1.

${ }^{6}$ Por. Passio SS. Perpetuae et Felicitatis, ed. H. Musurillo, The Acts of the Christian martyrs, Oxford 1972, 106-130 (z przekładem angielskim); ed. A.A.R. Bastiaensen, w: Atti e Passioni dei martiri, Milano 1987, 107-147, 412-452; ed. J. Amat, SCh 417, Paris 1996 (tekst łaciński i grecki Passio + przekład i komentarz + tekst łaciński i przekład Acta); ed. J. Leal, Acta latinas de mártires africanos, Madrid 2009, 57-137; ed. M. Formisano - E. Cantarella, La passione di Perpetua 
ratury hagiograficznej ${ }^{7}$. Składa się zasadniczo z dwóch podstawowych części, poprzedzonych wstępem i zamkniętych krótkim zakończeniem, zawierającym wezwania do męczenników.

Pierwsza z nich zawiera mniej więcej połowę utworu, a składa się z siedmiu fragmentów autobiograficznych następujących po sobie. Sześć pierwszych pochodzi od Wibii Perpetui, młodej arystokratki z Thuburbo Maius, a ostatni od Saturusa, człowieka świeckiego, przywódcy grupy przyszłych więźniów-męczenników. Wypowiedzi Pepetui są ułożone chronologicznie, tak jak następowały, i ukazują, jak ona przeżywała uwięzienie (suo sensu $)^{8}$. Są one dwojakiego typu: jedne $\mathrm{z}$ nich opowiadają o pobycie w więzieniu i skazaniu na śmierć, drugie zaś dają dokładne opisy doznawanych przez nią wizjii; tekst Saturusa daje jedynie opis jego wizji. Wszystkie te fragmenty są pisane na sposób bardzo barwny i żywy. Te zaś fragmenty autobiograficzne można podzielić w następujący sposób:

1. Opowiadanie Perpetui. Spotkanie Perpetui z ojcem, opis więzienia wewnętrznego oraz wyjścia z niego (1-3).

2. Wizja Perpetui. Saturus zwraca się do Perpetui z prośbą o zapytanie Boga, co ich czeka. Nazajutrz Perpetua ma wizję: wstępuje po drabinie, której strzeże smok, wchodzi do ogrodu, gdzie starzec częstuje ją serem (4).

3. Opowiadanie Perpetui. Spotkanie z ojcem w czasie przesłuchania, wydanie wyroku śmierci (5-6).

4. Wizja Perpetui. Perpetua widzi cierpiącego zmarłego brata Dinokratesa, za którego się modli, na wskutek czego Dinokrates może skosztować wody. Wizja przerwana jest opisem przeniesienia do obozu wojskowego (7-8).

5. Opowiadanie Perpetui. Oczekiwanie na męczeństwo. Spotkanie z ojcem (9).

e Felicita, Milano 2008; inne wydania: BHL 6634-6637; BHLns 6633, 6633b, 6634; 6635; Opracowania wybrane zob. J. Amat, Introduction + bibliografia, SCh 417, 9-94, 265-276; P. Monceaux, Histoire littéraire de l'Afrique chrétienne, I, Paris 1901 (repr. 1966), 70-96; H. Delehaye, Passions des martyrs et les genres littéraires, Bruxelles 1966², 49-55; J. Fontaine, Tendences et difficultés d'une prose chrétienne naissante: l'esthétique composite de la „Passio Perpetuae”, w: tenże, Aspects et problèmes de la prose d'art latine au III siècle, Torino1968, 69-97; R. Dodds, Pogaństwo i chrześcijaństwo w epoce niepokoju, thum. J. Partyka, Kraków 2004, $52-57$ (rozdział dość dyskusyjny); J.N. Brenner, Perpetua and his diary, w: Märtyrer und Märtyrerakten, Stuttgart 2002, 79120 (bibliografia). Przekłady polskie: tłum. M. Michalski, ALP I 138-142; A. Malinowski, OŻ IX (Męczennicy, Kraków 1991), 244-268.

${ }^{7}$ Por. Delehaye, Passions des martyrs, s. 49.

${ }^{8}$ Por. Passio SS. Perpetuae et Felicitatis 2, 3.

${ }^{9} \mathrm{O}$ wizjach w aktach męczenników por. E. le Blant, Les persecutions et les martyres, Paris 1893, 89-97; P. Courcelle, Les Confessions de S. Augustin dans la traditon littéraire, Paris 1963; M. Dulaey, Le rêve dans la vie et la pensé de St. Augustin, Paris 1973, spec. s. 41-47; J. Amat, Songes et visions. L'au-delà dans la littérature latine tardive, Paris 1985; G. Mertens, Les premiers martyrs et leur rêves, RHE 81(1986) 5-46; tenże, Les rêves dans les passions des martyrs. Analyse narrative, „Augustinianum” 44 (2004) 269-319; M. Dulaey, DSp XIV 1060-1066; M. Kaczmarkowski, Struktura pionowa tekstów: „Passio sanctarum Perpetuae et Felicitatis”, „,Passio sanctorum Iacobi” $i$,,Passio Sanctorum Montani et Lucii”, VoxP 11-12 (1991-1992) t. 20-23, 213-221. 
6. Wizja Perpetui. Opis walki i zwycięstwa Perpetui nad Egipcjaninem (10).

7. Wizja Saturusa ${ }^{10}$. Aniołowie przenoszą go i innych (męczenników) do ogrodu, gdzie spotykają innych męczenników i gdzie następuje pogodzenie zwaśnionych duchownych (11-13).

Te bardzo żywe opisy wizji są jednak dość luźno związane z opowiadaniem, a więc z opisem męczeństwa.

Wszystkie te fragmenty były napisane własnoręcznie przez Perpetuę i Saturusa:

„Haec ordinem totum martyrii sui iam hinc ipsa narravit, sicut conscriptum manu sua et suo sensu"

Tych jednak słów nie należy brać dosłownie, ponieważ w starożytności podkreślały one raczej to, kto jest autorem, a nie sposób, w jaki były spisane. Bardzo często bowiem w starożytności dzieła bywały dyktowane. Czy mamy tu do czynienia z napisaniem własnoręcznym czy też podyktowaniem, nie wiemy. Autor podkreśla tylko mocno, że one pochodzą od nich.

W drugiej części Męczeństwa znajdujemy opis dalszych losów uwięzionych i samego ich męczeństwa. Ta część pochodzi od anonimowego autora całości dzieła, który zebrał fragmenty napisane przez męczenników, złożył razem i opatrzył opisem ich męczeństwa. Ten opis dalszych losów męczenników został dokonany z polecenia Perpetui (mandatum), z jej fideiconsultum, to znaczy - Perpetua dała autorowi ścisłe polecenie, które musiał wykonać, co i jak ma napisać ${ }^{12}$. Ta więc część stanowi dalszy ciąg jej autobiografii. Tak więc dzieło składa się z fragmentów autobiograficznych i z opisu męczeństwa dokonanego wedle jej polecenia. Można więc powiedzieć, że całe Męczeństwo Perpetui i Felicyty, a więc także ta część, która pochodzi od anonimowego autora, ma charakter bardzo osobisty, silnie naznaczony osobowością młodej męczennicy.

Wydaje się, że istniał jakiś dziennik Perpetui i być może także Saturusa. Dziennik Perpetui zawierał opis skazania, pobytu w więzieniu i wizji. Autor Męczeństwa wybrał $\mathrm{z}$ niego najważniejsze fragmenty (insigniores visiones) $)^{13}$ i ułożył je w porządku, w jakim zostały one napisane ${ }^{14}$. Jakie jednak były kryteria tego wyboru? Czy autor interweniował w jej tekst? Nie wiemy, choć tego nie możemy wykluczyć. Należy jednak podkreślić jeszcze inny aspekt tych obszernych fragmentów dziennika Perpetui. Stanowi on jeden z trzech utworów literatury rzymskiej, której autorkami są kobiety. Pierwszym z nich są frag-

${ }^{10}$ Por. J.N. Brenner, The Visio of Saturus in the Passio Perpetua, w: Jerusalem, Alexandria, Rom. Festschrift A. Hilhorst, ed. F. García Martinez, Bonn - Leiden 2007, 55-73.

${ }^{11}$ Passio SS. Perpetuae et Felicitatis 2, 3, SCh 417, 106; tamże 14, 1, SCh 417, 152-154: „Hae visiones insigniores ipsorum martyrum beatissimorum Saturi et Perpetuae, quas ipsi conscripserunt".

${ }^{12}$ Por. tamże 16, 1; Leal, Acta latinas de mártires africanos, s. 127.

${ }^{13}$ Por. Passio SS. Perpetuae et Felicitatis 14, 1.

${ }^{14}$ Por. tamże 3,3 . 
menty elegii Sulpicii (I w. po Chr.) opisujące jej przeżycia miłosne, znajdujące się pośród dzieł Tibullusa ${ }^{15}$; drugim to właśnie fragmenty pamiętnika Perpetui, opisujące z kolei jej przeżycia religijne, trzecim zaś dziennik z podróży do Ziemi Świętej Egerii (IV w. po Chr.), opisujące jej wrażenia z pielgrzymki po miejscach świętych. W tym kontekście fragmenty te nabierają specjalnego znaczenia i warte są szczególnej uwagi, stanowią bowiem niesłychanie cenny materiał do poznania duchowego świata kobiety w starożytności.

2. Męczeństwo Montanusa, Lucjusza i ich towarzyszy (za cesarza Waleriana, prześladowanie w szczególny sposób dotyczyło duchownych, Kartagina, 24 II?, 259) ${ }^{16}$. To Męczeństwo i następne, o którym będziemy mówili, dotyczy faktów, które miały miejsce około pół wieku później i ma inną strukturę niż Męczeństwo Perpetui i Felicyty. Z punktu widzenia formalnego, dzieli się na dwie części (list i samo męczeństwo), zaś treściowego - z trzech (list, męczeństwo Montanusa, męczeństwo Flawiana). Jeśli chodzi o autentyczność utworu, P. Franchi de Cavallieri gromadzi argumenty za i przeciw jego autentyczności ${ }^{17}$.

Pierwsza część tego Męczeństwa zawiera List wyznawców do wspólnoty $w$ Kartaginie (1-11), który ma raczej formę homilii autobiograficznej o charakterze retorycznym niż listu. Choć list ten jest napisany przez „omnes in carcere" 18 , to jego autorem był prawdopodobnie jeden z wyznawców - Flawian, retor kartagiński, kochany przez swoich uczniów, którzy starali się go ocalić wszystkimi możliwymi środkami, nawet kłamstwem, okazując mu, jak mówi autor ,amicitia inimica" ${ }^{19}$. List jest typowo autobiograficzny i opisuje w pierwszej osobie cierpienia uwięzionych chrześcijan oczekujących na śmierć. Celem tego listu, jak mówią autorzy, jest podać przykład wielkości Boga i opisać ich cierpienia. Jest to więc cel raczej budowania wiernych, niż podawanie im informacji na temat męczenników.

${ }^{15}$ Por. Rzymska elegia miłosna, thum. A. Świderkówna, oprac G. Przychocki - W. Strzelecki, BN II 90, Wrocław 1955, 33-36.

${ }^{16}$ Por. Passio SS. Montani et Lucii, ed. H. Musurillo, The Acts of Christian martyrs, s. 414-437; ed. F. Dolbeau, La Pasion des Saint Lucius et Montanus. Histoire et edition du texte, REA 29 (1983) 39-82; ed. J. Leal, Acta latinas de mártires africanos, s. 211-251 (bibliografia). Inne wydania: BHL 6009-6010; BHLns; thum. polskie: A. Malinowski, VoxP 9 (1989) t. 17, $773-779$ (fragmenty); Opracowania: P. Allard, Les derniers persecutions du III ${ }^{e}$ siècle, Paris 18982 , 120-134; P. Monceaux, Histoire littéraire, II, Paris 1902 (repr. 1966), 165-178; P. Franchi de' Cavallieri, Gli Atti dei SS. Montano, Lucio e compagni, w tegoż: Scritti agiografici, I, Città del Vaticano 1962, 199-292 (z wydaniem tekstu); tenże, Nuove osservazioni critiche ed esegetiche sul testo della Passio Sanctorum Montani et Lucii, w tegoż: Note agiografiche, III, ST 22, Roma 1909, 3-31, 111-114; H. Delehaye, Passions des martyrs et les genres littéraires, Bruxelles 1966², 55-59; X. Dupuis, Hagiographie antique et histoire: l'exemple de la Passion du Lucius et de Montanus, REA 49 (2003) 253-265; Kaczmarkowski, Struktura pionowa tekstów, s. 216-220.

${ }^{17}$ Por. Franchi de Cavalieri, Gli Atti dei SS. Montano, s. 219-224.

${ }^{18}$ Por. Passio SS. Montani et Lucii 12, 1, ed. Musurillo, s. 224.

${ }^{19}$ Por. tamże 12, 4. 
To świadectwo dane przez męczenników jest uzupełnione przez anonimowego autora drugiej części, ponieważ, jak twierdzi on, męczennicy ze względu na swoją pokorę nie podali wszystkich wiadomości - stąd też dalszy ciąg utworu stanowi kontynuację listu. A co więcej, Flawian domagał się (hoc nobis iniunxit), by uzupełnić ten list szczegółowym opisem męczeństwa ${ }^{20}$. Ten anonimowy autor jest przyjacielem i prawdopodobnie również uczniem Flawiana, a na pewno świadkiem naocznym ich męczeństwa ${ }^{21}$. Także i ta część Męczeństwa jest napisana stylem retorycznym, pełnym wykrzykników - J.B. de Rossi porównuje jego język z językiem Kommodiana ${ }^{22}$. Dzieli się ona na dwie części: najpierw opowiada męczeństwo Montanusa i Lucjusza, a następnie przechodzi do męczeństwa Flawiana, w której przedstawia również jego wizje, które mu podyktował sam Flawian - jest to więc także w pewien sposób przedłużenie listu.

Męczeństwo to zawiera, podobnie jak Męczeństwo Perpetui i Felicyty, opis cierpień znoszonych przez innych więźniów, a także opis czterech wizji, a więc wizję Renusa (wizja męczenników podążających ku męczeństwu [5]), wizję kapłana Wiktora (Chrystus w postaci dziecka przepowiada mu jego męczeństwo [7]), wizję Kwartilozy, żony i matki uprzednio umęczonych męczenników (pojawia się syn, który jej przepowiada męczeństwo, a następnie młodzieńcy, którzy jej ofiarują czarę mleka [8]) i w końcu wizję Montanusa (przeniesiony do ogrodu widzi na sobie ranę, wynik sporu z kapłanem Julianem [11]).

W części poświęconej Flawianowi mamy również opisy wizji spisane przez niego samego i z jego polecenia: zawierają one rozmowę z biskupem Cyprianem (jesteśmy rok po jego męczeństwie), wizję człowieka, który mu przepowiedział jego ścięcie i w końcu wizję ostatnio umęczonego biskupa Sukkcensusa, który przepowiada, że wkrótce przyjdzie czas jego męczeństwa i domaga się od niego pojednania z kapłanem Julianem (wszystkie te wizje znajdują się w rozdziale 21 ).

W tej drugiej części Męczeństwa fragmenty autobiograficzne stanowią opisy wizji i są o wiele krótsze niż te, które mamy w Męczeństwie św. Perpetui $i$ Felicyty i dużo mniej plastyczne; stanowią one tylko nieznaczną część samego Męczeństwa, natomiast w przeciwieństwie do tamtego utworu, są dobrze osadzone w treści tego Męczeństwa. Ponadto, co jest charakterystyczne dla tych dwóch utworów, zawierają one apel o pojednanie się skłóconych duchownych.

3. Męczeństwo Mariana i Jakuba (za czasów cesarza Waleriana, Lambesa w Numidii, 30 IV 259) $)^{23}$. To Męczeństwo przynosi nam jeszcze inny typ

\footnotetext{
${ }^{20}$ Por. tamże 12,15 i 21.

${ }^{21}$ Por. tamże 19, 1: ed. Musurillo, s. 232: „Illic nos in latere eius constituti eramus ita ut manus manibus teneremur".

${ }^{22}$ Por. „Bolletino di Archeologia Cristiana” 1880, 66-68.

${ }^{23}$ Por. Passio Mariani et Jacobi, ed. H. Musurillo, The Acts of the Christian martyrs, s. 194213; ed. J. Leal, Acta latinas de mártires africanos, s. 179-209 (bibliografia); inne wydania: BHL
} 
autobiografii: autor nie jest tylko naocznym świadkiem opisywanych faktów, ale także w nich uczestniczy ${ }^{24}$. Lenain de Tillemont uważa go za ucznia św. Cypriana. Co zaś stanowi ciekawostkę, to fakt, że autor raz pisze w pierwszej osobie - kiedy wraz z męczennikami uczestniczy w ich losie, a raz w trzeciej - kiedy jest tylko świadkiem wydarzeń. Autor został zaaresztowany z kilkoma członkami kleru, a następnie wypuszczony, prawdopodobnie jako człowiek świecki, jako że w tym prześladowaniu Waleriana ścigano przeważnie duchownych. Uwięzieni przyszli męczennicy proszą więc uwolnionego towarzysza, aby spisał ich męczeństwo, które będzie mogło służyć jako wzór dla przyszłych pokoleń.

W tym Męczeństwie znajdujemy znów opis kilku wizji, choć jeszcze bardziej bezbarwnych i nijakich, jak w poprzednim. Są to ,podwójna wizja” Jakuba i Mariana: Marian opowiada widzenie przed trybunałem, w którym uczestniczy także św. Cyprian, który go zaprowadził do źródła wody żywej (6); gdy to opowiadanie usłyszał Jakub, przypomniał sobie, że przed kilkoma dniami miał widzenie, w którym widział człowieka wzywającego go, aby poszedł za nim (7). Ciekawe jest także widzenie ascety świeckiego Emiliana, który opowiada swoje widzenie spotkania ze swym bratem-poganinem i dyskusję z nim na tematy wiary (8). Pod koniec Męczeństwa znajduje się wizja Jakuba, który wraz z Marianem bierze udział w uczcie, urządzonej przez umęczonego biskupa Agapiusza (11). Na końcu Męczeństwa znajdujemy dość nietypową scenę: męczennicy, tuż przed swoją śmiercią mają widzenia, które opowiadają uzupełniając się nawzajem; na końcu Marian wygłasza proroctwo (12).

Jeśli chodzi o anonimowego autora tego Męczeństwa, to możemy powiedzieć, iż jest to człowiek prosty i pełen dobrej woli, który sądzi, że okraszając swoją relację dość banalną retoryką, stworzy dzieło literackie, którym ten utwór bynajmniej nie jest, tym bardziej, że jego kompozycja jest dość chaotyczna; to samo zresztą możemy powiedzieć o poprzednim Męczeństwie.

4. Wnioski: a. Autobiografia. $Z$ tego, co powiedzieliśmy wyżej, wynika, że mamy tu do czynienia z trzema różnymi dziełami, w których element autobiograficzny jest stosowany w różny sposób, choć znajdujemy również podobne elementy. Pod względem treściowym we wszystkich tych trzech dziełach znajdujemy dwa typy fragmentów autobiograficznych: opisy męczeństwa

131-132 (Agapius itd.); BHLns; tłum. polskie: A. Malinowski, VoxP 9 (1989) t. 17, 766-773 (fragmenty). Opracowania: Allard, Les derniers persecutions, s. 135-139; Monceaux, Histoire littéraire, II, s. 153-165; P. Franchi de' Cavallieri, La Passio SS. Mariani et Iacobi, ST 3 (1900) 7-73; H. Delehaye, Passions des martyrs et les genre littéraires, Bruxelles 1966², 59-62; J. Aronen, Marianus' Vision in the Acta of Marianus and Jacobus. An Analysis of style, structure and composition, WS 97 (1984) 169-186; Augustinus, Sermo 284, PL 38, 1288-1293; Miscellanea Agostiniana, I, Roma 1930, 719; M. Simonetti, La Passione di Mariano e Giacomo e il sermone 284 di sant'Agostino, „Orpheus” 4 (1957) 76-82 (sermo plus ancienne que la passion); Kaczmarkowski, Struktura pionowa tekstów, s. 220-221.

${ }^{24}$ Por. Passio SS. Mariani et Iacobi 1 i 4. 
w szerokim tego słowa znaczeniu (aresztowanie, pobyt w więzieniu, wyrok) oraz opisy wizji męczenników. W Męczeństwie św. Perpetui i Felicyty elementy autobiograficzne zawierają niemalże połowę dzieła i stanowią zwarty blok tematyczny. Znajdujemy wśród nich obydwa wyżej wspomniane tematy, choć odgrywające inną rolę. Opowiadania męczeństwa są związane harmonijnie całością utworu, natomiast wizje, zarówno te Perpetui, jak i Saturusa, są dość luźno związane z treścią dzieła.

W Męczeństwie Montanusa i Lucjusza pierwszą jego część stanowią fragmenty autobiograficzne: jest to list-homilia, w której męczennicy opisują swoje cierpienia w więzieniu. Wizje Flawiana i innych męczenników, znajdujące się w drugiej części Męczeństwa, odgrywają w nim mniejszą rolę, są dość nijakie, ale za to ściślej powiązane z treścią utworu. Jak się wydaje, wizje, jeden z elementów autobiograficznych, stanowią dla autorów część zasadniczą ich opisu; autor Męczeństwa Perpetui i Felicyty zdaje się nazywać wizjami nawet całość utworu ${ }^{25}$.

We wszystkich tych utworach znajdują się obszerne opisy wizji, szczególnie w Męczeństwie Perpetui i Felicyty, ale także i w innych Męczeństwach, natomiast w Męczeństwie Montanusa i Mariana i Jakuba wizje są zazwyczaj bardzo zwięźle i krótko streszczone; w końcu znajdujemy tylko wspomnienia o wizjach. Męczeństwo Mariana i Jakuba jest całe autobiografią, w której przeważa element opisujący samo męczeństwo; wizje są jeszcze krótsze i jeszcze mniej znaczące, niemniej istnieją.

b. Zapis. Czytając te trzy teksty znajdujemy dość niespodziewane stwierdzenie: dla męczenników opisanie ich męczeństwa i wyrażenie na piśmie ich przeżyć duchowych, jest niesłychanie ważnym elementem, stąd też spisują je sami, dyktują innym lub też polecają je spisać. Widać to szczególnie w Męczeństwie św. Perpetui i Felicyty, gdzie redaktor tego tekstu notuje wizje, choć nie mają one wiele wspólnego z samym przebiegiem treści dzieła, a są jakby na marginesie akcji: są jednak elementem tak cennym, zdaniem autora, że choć nawet nie związane $\mathrm{z}$ treścią, muszą zostać zanotowane.

Jeśli chodzi o samych męczenników, o których była mowa, to nie możemy wątpić, że umieli oni pisać i czytać oraz byli zdolni nie tylko opisać wydarzenia, ale także wyrazić swoje zdanie; znali nawet nieco retoryki, choć posługiwali się nią dość nieporadnie. Wyrażano natomiast wątpliwości, co do tych umiejętności u Perpetui. Jest to jednak niesłuszne. Mimo że w tej epoce wiele kobiet nie umiało ani pisać ani czytać, to tu mamy do czynienia z kobieta, pochodząca z arystokracji miejskiej o pewnej kulturze, która otrzymała nawet dość dobre wykształcenie (liberaliter instituta) ${ }^{26}$, a nawet znała, przynajmniej w mowie, język grecki ${ }^{27}$. Watpliwości więc, co do możliwości napisania przez nią pamiętnika, są zupełnie nieusprawiedliwione.

\footnotetext{
${ }^{25}$ Por. Passio SS. Perpetuae et Felicitatis 3, 5; Passio SS. Montani et Lucii 3, 5; 4, 2.

${ }^{26}$ Por. Passio SS. Perpetuae et Felicitatis 2, 1.

${ }^{27}$ Por. tamże 13.
} 
Czy można jednak było pisać pamiętnik w więzieniu? Listy z więzienia pisał św. Paweł (listy więzienne), św. Ignacy Antiocheński czy św. Cyprian ${ }^{28}$; o pisaniu listów z więzienia donosi również Euzebiusz z Cezarei ${ }^{29}$. Z pewnością, nie było to możliwe w ciemnościach więzienia wewnętrznego, o których pisze Perpetua i inni, ale tam przebywała ona tylko pewien czas $^{30}$. Gdy jednak przeszła do innej części więzienia, stało się to możliwe: miała światło i możliwość pisania, choć prawdopodobnie utrudnione, a i czasu im chyba nie brakowało, by spisać swoje przeżycia. Więźniowie pisali je więc samodzielnie (manu peropria), ale także mogło być tak, że je dyktowali - jak to widzieliśmy - przybyszom spoza więzienia lub współwięźniom. Częste kontakty z światem zewnętrznym pozwalały na przyniesienie więźniom materiałów piśmiennych, a następnie wyniesienie tekstu na zewnątrz. W licznych pismach o męczennikach spotykamy diakonów odwiedzających ich, pomagających im i przynoszącym żywość - historia wydobycia męczenników z więzienia wewnętrznego za łapówkę jest tu emblematyczna ${ }^{31}$; oni też przynosili im Eucharystię. I nie byli to tylko diakoni, ale odwiedzało ich także wielu innych gości ${ }^{32}$. Wiemy z pewnością, że Perpetua pisała coś w rodzaju dziennika, a choć znamy tylko jego fragmenty, zanotowane przez autora Męczeństwa, nic więcej o nim powiedzieć nie możemy. Czy taki sam dziennik więzienny pisał Saturus, czy też tylko spisał lub podyktował swoją wizję? Nie możemy nic powiedzieć33.

Jak ten dziennik (czy te dzienniki) zostały wykorzystane przez autora? List do wspólnoty z Męczeństwa Montanusa i Lucjusza wykorzystano w całości i wcielono do tego utworu. Jeśli chodzi o Męczeństwo Perpetui i Felicyty, autor dokonał wyboru ${ }^{34} \mathrm{z}$ jej dziennika, ale nic nie wiemy o formie dziennika młodej patrycjuszki poza tym, że znajdowały się tam opisy pobytu w więzieniu i wizji. Nie wiemy, wedle jakich kryteriów autor wybrał teksty i wykorzystywał ten dziennik. Nie wiemy, czy dokonywał on jakichś zmian w tekście, czy też nie, i czy ewentualnie wprowadził je do tekstu zredagowanego przez siebie Męczeństwa.

W Męczeństwie Montanusa, Lucjusza i ich towarzyszy wiemy, że autor z powodu niekompletności danych, wynikających z pokory męczenników, którzy opuścili pewne wiadomości, musiał uzupełniać wiadomości ${ }^{35}$. Wizje Flawiana autor otrzymał w ostatniej chwili przed jego męczeństwem i to samo możemy powiedzieć o innych widzeniach zawartych w tym Męczeństwie.

\footnotetext{
${ }^{28}$ Por. np. Epistolae 22, 23 i 31.

${ }^{29}$ Por. Eusebius, HE V 3, 4 - listy montanistów; VI 11, 5 - męczennicy aleksandryjscy.

${ }^{30}$ Por. Passio SS. Perpetuae et Felicitatis 3; Passio SS. Montani et Lucii 4: nie ma tu jednak użytego słowa „więzienie wewnętrzne”, tylko jest mowa o wielkich ciemnościach, co na nie wskazuje.

${ }^{31}$ Por. Passio SS. Perpetuae et Felicitatis 3.

${ }^{32}$ Por. tamże 9 i 16; Passio SS. Montani et Lucii 4 i 9.

${ }^{33}$ Por. Passio SS. Perpetuae et Felicitatis 11: „Saturus visionem suam edidit quam ipse conscripsit”.

${ }^{34}$ Por. tamże 14: „Hae visiones insigniores ipsorum martyrum beatissimorum Saturi et Perpetuae". Jest tu mowa tylko o wizjach, ale można to wziąć jako pars pro toto.

${ }^{35}$ Por. Passio SS. Montani et Lucii 12.
} 
Odnośnie do tych trzech Męczeństw możemy powiedzieć, że sami męczennicy domagali się, by zostały spisane ich doświadczenia, cierpienia i wizje ${ }^{36}$. Jeśli chodzi o Perpetuę, to się domagała, by jej dziennik został przepisany wiernie tak, jak go napisała, i w takim samym porządku; terminologia tego fragmentu potwierdza wagę, jaką przykładała do tej prośby ${ }^{37}$.

Jednym słowem, możemy powiedzieć, że nie wiemy prawie nic o warsztacie pisarskim autorów poszczególnych Męczeństw i o sposobie wykorzystywania przez nich materiałów autobiograficznych męczenników.

c. Cel. Nacisk, jaki kładli męczennicy na to, by ich doświadczenia męczeńskie zostały spisane, nieco nas zadziwia. Dlaczego to naleganie? We wszystkich trzech Męczeństwach znajdujemy niemalże taką samą motywację. Celem ich było to, by ich doświadczenia przekazano przyszłym pokoleniom, ponieważ „potwierdzają one łaskę Bożą i budują ludzi... tak, że nie będą oni już lękliwi ani nieufni względem łaski"38, byli oni bowiem przykładem dobroci Boga a ponieważ ,przykłady starożytnych służyły jako wzory: wyciagnijmy i my korzyść z tych nowych przykładów" ${ }^{39}$. Męczeństwa więc były pisane nie z powodu ciekawości historycznej, ale po to, aby budować wiernych; spisanie ich więc było formą służby bliźnim. I z tego właśnie powodu męczennicy nalegali, aby ich cierpienia i męczeństwo zostały opisane wiernie, aby mogły służyć przyszłym pokoleniom.

Pozostaje więc pytanie, dlaczego tylko w środowisku afrykańskim autorzy tych trzech Męczeństw wykorzystali elementy autobiograficzne. Wydaje się, że rozwiązanie jest proste: autorzy dwóch utworów, to jest Męczeństwa Montanusa, Lucjana i towarzyszy oraz Męczeństwa Mariana i Jakuba ulegali wpływowi Męczeństwa św. Perpetui i Felicyty oraz wykorzystali, jak ich autor, zapiski męczenników dotyczące ich przeżyć fizycznych i duchowych, które ci im przekazali w różnej formie. Tu jednak kończy się porównanie, które ogranicza się tylko do formy; treść, mimo że zawiera te same dwa elementy, opisy pobytu w więzieniu i wizji, jest we wszystkich tych utworach dość zróżnicowana. I w ten sposób powracamy do pytania postawionego na początku: mimo wszystkich różnic Męczeństwo sławnych męczennic kartagińskich pozostaje modelem, w który inni męczennicy wprowadzają swoje przeżycia.

Jeśli jednak tak się sprawy mają pozostaje jeszcze jedno pytanie: $\mathrm{w}$ jakim stopniu było powszechne spisywanie swoich przeżyć przez męczenników w więzieniach? A więc, czy spisywanie przeżyć więziennych było również

${ }^{36}$ Por. np. Passio Mariani et Jacobi 1, 3, ed. Musurillo, s. 194: ,,martyres in notitiam fraternitatis per nos venire iusserunt".

${ }^{37}$ Por. Passio SS. Perpetuae et Felicitatis 16, SCh 417, 1: „Mandatum sanctissimae Perpetuae, immo fideicommissum eius exsequimur". Na temat terminu fideicommissum zob. Leal, Acta latinas de mártires, s. 127.

${ }^{38}$ Passio SS. Perpetuae et Felicitatis 1, 1, SCh 417, 98; zob. też Passio SS. Montani et Lucii 1 i 10; Passio Mariani et Jacobi 1.

${ }^{39}$ Passio SS. Montani et Lucii 22, ed. Musurillo, s. 236. 
w zwyczaju w innych regionach Cesarstwa, jeśli tak, to gdzie i w jaki sposób. Byłoby ciekawe przebadanie z tego punktu widzenia literatury o męczennikach. Odpowiedź na te pytania pozostaje jednak poza zakresem niniejszej pracy.

\section{THE AUTOBIOGRAPHICAL ELEMENTS IN THREE OF AFRICAN PASSIONS FROM III CENTURY}

\section{(Summary)}

Three African Passions from III century contains the characteristic element: autobiographical parts, which we do not find in other passions of ancient period. There are Martyrdom of Saints Perpetua and Felicity (203 c.), Martyrdom of Montanus, Lucius and their companions (259 c.) and Martyrdom of Marianus and Jacob. This all three Passions are authentic and principally autonomic of themselves, but two latest patterns of popular in Africa Passion of Perpetua and Felicity in some of elements. The autobiographical elements relates to description of the Passion as well as visions, which were experienced in prison. That latest mentioned element does not have to be understood as a influence of Montanism over this works - both this elements are given in different form and included in different way at the same work. The artistic level of descriptions is also different from the most beautiful pieces of Passion of Perpetua and Felicity to rather simple followed pieces of the work. Martyrs were really involved writing in prison and handed-down descriptions of themselves martyrdom to build future generations and give them shinning examples. 
